\title{
ANALYSIS OF TEACHER CERTIFICATION POLICY \\ IMPLEMENTATION THROUGH EDWARD III APPROACH IN \\ ACEH TAMIANG REGENCY, INDONESIA
}

\section{Nurbaiti NURBAITI*}

\section{Humaizi}

\section{Beti NASUTIOON}

*Universitas Sumatera Utara, Master of Development Studies,nurbaity.903@ gmail.com

\begin{tabular}{ll}
\hline $\begin{array}{l}\text { Article history: } \\
\text { Accepted } 20 \text { May } 2019 \\
\text { Available online 10 July } 2019\end{array}$ & A s t r a c t \\
& This paper aims to study and analyze the implementation of teacher certification regulations in Kuala \\
Keywords: & Simpang, Aceh Tamiang Regency. This analysis uses several factors found by Edward III in the form \\
$\begin{array}{l}\text { Policy Implementation, } \\
\text { Certification, }\end{array}$ & of communication, resources, disposition, and bureaucratic structure. A qualitative descriptive \\
Teacher's Professionalism, & approach is used in this paper. The results found showed that in the process of applying certification \\
Edward III Approach & at the Aceh Tamiang education office, it had not yet proceeded effectively demanding several \\
& constraints such as lack of facilities and infrastructure, and inconsistent regulations that made it \\
& difficult for teachers. This has caused teachers to be unable and ineligible in completing lesson plans, \\
there are still some teachers who are found to lack discipline and bad attitudes and certification are & only considered for welfare and personal gain. Thus it can be stated that the certification program \\
has not played an important role in teacher professionalism.
\end{tabular}

\section{Introduction}

Education is considered as the construction of knowledge, competency, and potential development, where it has transformed drastically. Besides, students are expected to be able to learn without the limitation of time and place. Another important issue in education is the means to provide opportunities for students to make them think while they are solving problems, analyzing, and synthesize their knowledge at every level of their studies (Prasertcharoensuk, Somprach, \& Ngang, 2015). To be able to meet the objectives of education, the teacher has an important role as individuals who devote themselves to the world of education. Teacher plays a pivotal role in the entire academic educative process and pupil academic achievement (Fahmi, Maulana, \& Yusuf, 2011) (Khan, 2013). An excellent quality of education is closely related to the professionalism of the teacher and their performance in educating the students. The acknowledgment of the position of the teacher as a professional as referred to is evidenced by the educator's certificate. Teachers are required to have academic qualifications, competencies, educator certificates, physical and mental health, and have the ability to realize national education objectives (Kusnandar, 2018).

The Indonesia's Law number 14 of 2005 regarding teachers and college teacher (Dosen), forcefully argues that teachers are professional educators with the primary task of educating, teaching, guiding, directing, training, assessing, and evaluating students who may be in the school-age informal education, primary education and secondary education (Bakar, 2018). Teacher certification has become the basis for ensuring the establishment of professional teachers to realize the goals of national education. The implementation of teacher certification is expected to be a solution in achieving the standards of qualified and professional teachers (Kurniawan, 2011). The program of teacher certification was started in 2006 with a target of certifying around 2.3 million elementary and secondary (middle school) teachers in 2015 . With this large-scaled certification program, all teachers in Indonesia will eventually be certified by 2015. The budgetary cost of this program is estimated to be about US $\$ 460$ 
million. To the best of our knowledge, with this program's magnitude, this could be the biggest teacher certification program in the developing world, if not in the world (Fahmi, Maulana, \& Yusuf, 2011).

In terms of implementing regulations specifically the teacher certification program regulation. These factors are communication and socialization, availability of resources, the attitude of the officer, regulation procedures and coordination between the parties involved. These four factors are the benchmarks for a successful implementation of teacher certification which will be discussed in the next chapter. Of these four factors, we will be able to assess whether the implementation of teacher certification has gone according to the direction of the regulation or not, and in terms of professionalism, there are three competencies that must be fulfilled by certified teachers, namely pedagogic competence, professional competence, and personality competence.

The implementation of teacher certification which refers to the Minister of National Education Regulation Number 5 of 2012 regarding teacher Certification in Occupations is carried out in several stages to adjust with the availability of funds, both the funding for certification and funding for professional educator additional allowances for the teachers who pass certification. At the beginning of its implementation, which began from 2007 to 2017 , many obstacles were found both in terms of regulations that were inconsistent and the technical implementation in the field which of course involved several parties, namely the district education office, and the certified teachers. The formulation of teacher certification regulation that sounds ideal can build hopes for a better quality of education by improving the teacher's professionalism and the quality of education. This paper will discuss the matter in a more depth discussion regarding the implementation of certification regulation in the professionalism of teachers, especially in the Kuala Simpang District of Aceh Tamiang Regency.

\section{Methodology}

The data for this paper were collected using descriptive methods through a qualitative approach, therefore, it will describe and explain the implementation of teacher certification policy in the Kuala Simpang District of Aceh Tamiang Regency. This region has criteria as a data source for the reason that this region has a teacher who has had certification from 2007 to 2018. In addition, the author chose elementary school considering that the institution is the fundamental basis of the education process at an early stage which portraits the teachers in elementary schools as ones who will determine the ability of students in the next stage of education. The informants in this paper consisted of the management committee of the teacher certification in the Tamiang District Education Office (of 2 people), elementary school teachers who had received certification ( 5 people) and 1 school supervisor.

\section{Result and Discussion \\ 2.1. Analysis of Implementation of Primary School Teacher Certification Policies in Kuala Simpang District, Aceh Tamiang District}

Edward III (Edward, 1980) states that policy implementation is the stage of policy-making where policymaking is a part of legislative action, issuance of executive orders, submission of decisions or result for the inferior, or the promulgation of regulations and policy consequences for the people affected. Referring to the theory by Edward III, the implementation of the policy is influenced by five factors, namely: Communication, Resources, Disposition (Attitudes of TheImplementer) and Structure of Bureaucracy.

\subsubsection{Communication}

In teacher certification, communication is where the policymakers deliver information towards the policy implementers and then forwarded to the certification participants. These ways of information delivery from the policy implementers to the certification participants are in the form of socialization. In the next section, three communication factors will be discussed, namely the delivery of messages, clarity and consistency.

\subsubsection{Delivery of Message}

Message delivery is the initial stage of communication. In the implementation of the teacher's certification, the information is delivered through socialization. If the socialization runs smoothly, the implementation process will run effectively, and vice versa. The data found shows that since 2007 the Education Agency of Tamiang Regency has carried out socialization on teacher certification. The socialization activities were conducted twice a year from 2007-2011. The source who delivered the socialization activity was able to convey information clearly and had experience with the teacher certification program. From 2012 until now, the socialization has not been conducted again, therefore, the certification candidates must be active to find information about the certification through friends, the internet and the website of the Ministry of National Education.

\subsubsection{Clarity}

A policy made by the policymakers must contain clear objectives. The clarity of policy objectives needs to be communicated properly with the implementers. Implementation of the policy must be accepted by all personnel and those must understand it 
clearly and accurately regarding the purpose and objectives of the policy made. The certification program in Tamiang Regency is intended to asses the professionalism of the teachers by taking the test with the targeted value in order to obtain an educator certificate stating that the teacher is professional. But this statement has contradiction with the one stated by the teacher who has gone the certification process who said that the purpose of the certification policy is unclear, because if you want to asses the professionalism of teachers only from their competency test scores, the officer from the headquarter office should immediately come to review the performance of the certification candidates, because there are still many teachers with adequate quality but are not certified. Based on the experience of an informant who is a certified teacher, the information obtained is as follows:

"The information given at the time of socialization is quite clear, but we were not given the certification manual, and indeed the purpose of this certification is to see the professionalism of the teacher, but not necessarily from the initial competency test and after the PLPG test, in my opinion, it is better for the authorized officers to come down to schools to directly reviews the performance/expertise of a teacher when they teach in the class.

\subsubsection{Consistency}

According to Edward III, the order given in the implementation of the policy must be consistent and clear to be stipulated or implemented. If the order was given often changes or inconsistent, it may cause confusion for the implementer. Therefore consistency must also receive attention in a communication. Consistency in this study can be seen from the implementation of the regulations applied. It can be stated based on the data above data that in the implementation of the teacher certification policy in the Kuala Simpang District, Aceh Tamiang Regency is still not consistent where the regulations themselves still change frequently every year. These changes lead to inconsistent policy and are overwhelming for the policy implementers and teachers who receive the certification. There are several problems which might be causing this inconsistency in certification policies, namely consistently change regulations and implementation which are happening every year and the longer the regulation is the more difficult it will be for teachers, where the competency test score standards are high and difficulties of using computer-generated exams while there are still many teachers who are not able to use the technology. As mentioned by a certified teacher in the interview as follows:

"Certification regulations often change without being previously socialized to us every year thus creating confusion and the regulations are increasingly complicated, where the test scores have to be high and test using computers, where there are still teachers who are confused about using the computer during the test"

\subsubsection{Resources}

Resources are useful for supporting the implementation of a policy. Without adequate resources, the implementation of a policy will be disrupted.

\subsubsection{Staff}

Resources are one of the factors that must be present in the implementation of the policy if the staff of the policy implementer is lacking in terms of their amount, then the wellbeing of the policy will be disrupted. Likewise, if the staff does not have the competence, the policy will not be optimally run. Resources in implementing the teacher certification policy are in the staff whose carry out the teacher certification program. In the context of this paper, the staff in question were the staff of the Aceh Tamiang Education Agency. The staff of the Aceh Tamiang Education Agency is responsible for the successful implementation of the teacher certification program in the Kuala Simpang District. The number of staff in this area can be considered to be insufficient and sometimes lead to long lines of the queue when submitting the teacher certification files. Whereas for the service of the resources is quite excellent where each work is conducted properly but there is still embezzlement of funds and bribery conducted by the certification committee staff in the education department in collecting the certification files.

\subsubsection{Information}

All information regarding the certification program should be obtained by the teacher through the regional Education Agency. The teacher is the object of the certification policy and the Aceh Tamiang Education Agency is the regulator and board of the teacher, Therefore the agency must play an active role in providing information for the teachers. From this factor, it can be stated that teachers receive get information quite well, even though the information they obtained must be received through the principal or operator. The process of delivering information carried out by the Education Agency is carried out with assistance from the operator /principal.

\subsubsection{Authority}

Authority is one an important component in implementing policy. The implementing board of the teacher certification policy has a certain authority in order to be able to implement the policies imposed. The implementing board must not violate the authority of other implementing agencies. Implementers of teacher certification policy must get rid of their desire to take advantage of individuals or groups. Currently, the staff from the Education 
Agency have used their respective authorities in accordance with their positions.

\subsubsection{Facility}

Facilities are an important factor in implementing policy. An organization which has sufficient and competent staff if it is not supported by adequate facilities, the implementation will be hampered. The facilities in the implementation of the teacher are computer rooms, as well as AC, which is a facility to held the socialization for the certification participants, as well as facilities in the PLPG (Teacher Professional Training and Education) training in the headquarter for competency tests for the certification participants who must receive attention therefore the implementation of the policy can be implemented well.

The facilities of the Aceh Tamiang Education Agency to for the socialization are still lacking where there is still no airconditioning equipment available and with the number of participants, it may set back the comfort of participants of the socialization. In implementing the Teacher Professional Training and Education (PLPG), the learning room facilities are adequate, the module is provided by the implementer, as well as accommodation, consumption, and transport facilities are funded by the certification organizers, but as time goes on, the teachers who take PLPG in 2015 the transport costs were no longer covered by the certification organizer. And for the year 2018 the facilities for the certification participants have been significantly reduced, one of which is for accommodation costs where teachers must pay for their own lodging during the training held for 3 months, as well as for the transportation costs, to the point where there are teachers who resign as certification participants due to the facilities which are alarmingly inadequate.

\subsubsection{Disposition}

Disposition plays an important role in the success or failure of the implementation of a policy. Disposition is the attitude or character of the implementor. Disposition will determine the success of policy implementation. If the implementer has a positive attitude, he/she may be able to run the policy well. A positive attitude is shown by the ability to conduct tasks properly, responsibility and sincerity in carrying out their duties. And if the implementer of the policy has a negative attitude, they won't be able to implement the policy with correct, the implementation of the policy will also be hampered. These negative attitudes usually pose as lazy attitude, lack of motivation and lack of awareness of their responsibilities. The disposition is divided into three parts, namely: disposition effects, placement of staff, and incentives.

\subsubsection{Disposition Effect}

The effect of the Disposition in this paper is focused on commitment. Commitment is proven by how the implementor in implementing the policies, goals or changes as well as changes that have been achieved by the implementors for the teacher certification program policies. If the implementation has been conducted effectively, then the implementers must acknowledge what to be done and the ability to implement it.

The staff has committed to working properly thus the implementation of the teacher certification policy is going well, besides that the staff also support this policy, therefore, the teachers can live in a better life and as a motivation for the teacher's enthusiasm in their professional life. The teachers argue that there are still some parties who reluctant with the tasks and the rules set by policymakers. With this attitude, the teacher cannot work optimally. As mentioned by one of the certified teachers below:

"I am very supportive of this policy, as a teacher who received the certification I have the obligations such as required to teach at least 24 hours a week, must complete the syllabus, as well as making lesson/learning plans. Indeed, after the certification, there are many teachers with improved living standards but also the certification comes with many demands and responsibility, or in other words, the workload is increasing, and some teachers also complain the same.

\subsubsection{Placement of Staff}

The policymakers must arrange and place their staff appropriately and selectively. Appropriate placement of staff will ensure good policy implementation. In order for the implementation of the policy to run optimally, staff who are in the implementation of the policy must be placed according to their respective expertise. In the implementation of the teacher certification program, the staff placement in question is the staff placement of the Aceh Tamiang Regency Education Agency. In the Aceh Tamiang that staff placement has been adequately placed according to their respective expertise and fields, the staff are not selected but instead the leader directly appoints who is placed in the field of the certification program, then is given a letter of assignment to carry out the teacher certification program, then the staff is given training they required.

\subsubsection{Incentives}

Incentives are given to encourage one's motivation to carry out tasks. In a teacher certification program, incentives are given to the teachers who have received an educator certificate. Providing incentives for the teacher certification program is referred to as a professional allowance. Professional allowance is obtained by teachers who have received an educator certificate. Teachers who have received an educator certificate are given benefits to improve their welfare. The provision of these benefits is intended 
to motivate the teachers in increasing their professionalism. Based on the results of interviews regarding the incentives, the official staff received the incentives right from the Regional Budgetary Funds. The incentives are given with the amount of equal to one-time salary for every 3 months, the certification allowance fund is indeed received by the certification teachers at each period but the allowance often given late.

\subsubsection{Bureaucratic Structure}

The bureaucratic structure according to Edward III is divided into SOPs (Standard Operating Procedures) and the sharing or disposition of responsibilities. SOP is very useful in order to make the bureaucray system run consistently, effectively, efficiently, and not conflicted with the existing regulations.

\section{Standard Operational Procedures}

The SOP is a list of governance in conducting certain matters which contains the instructions and regulation within the organization. Implementers of the policy must carry out their activities based on exist the SOPs consistently, effectively and efficiently. In the context of implementing teacher certification policy, the SOP is replaced with technical guidelines. Technical guidelines are similar to the SOP, which regulates the teacher certification process to be implemented properly.

\section{Distribution of Responsibility}

The availability of clear regulation regarding the authority and responsibility of implementing the teacher certification program has already been provided by the District Education Office specifically on the main tasks of each staff. The disposition of authority and responsibility run well along with the coordination of each party.

\subsection{The role of ceritification for elementary school teacher's professionalism in Kuala Simpang District}

In order to become a teacher with a high level of professionalism, real efforts are needed as expected for the improvement of the students and national education. Through certification, teachers are required to become professionals because certified teachers mean they have fulfilled the competencies in both pedagogical, professional, and personality competencies. Teachers who have received certification are ones who have the expertise in their respective fields of education, therefore, they are referred to as professional teachers.

Teachers who already have the certificate are expected to carry out their duties professionally. Various tasks conducted by the certified teachers are a form of the teacher's commitment to continue to improve their quality. This commitment can be demonstrated through consistent or improvement in performance in accordance with the expectations and goals of national education. When an educator already has a certificate, people will assume that the educator is a professional educator. The indication is because the person has passed the competency test. However, there is no guarantee that an educator who has passed the competency test will become a professional educator. Professionalism is a term obtained after going through a certain process.

Based on Law Number 14 of 2005, the purpose of teacher certification is to see the professionalism of the teachers. But in reality, based on the data found it shows that certification has not played any role in the professionalism of the elementary school teachers in Kuala Simpang District, Aceh Tamiang. This can be seen from the lack of teacher's quality in their professional competencies such as the teachers' ability to work on the Learning Plan, even though the plan is very important for the teachers to teach in class, but in reality there are many certification teachers who employ other people to work on their learning plan. The current change in the curriculum from KTSP to Curriculum 13 caused the teachers to have difficulties in making their learning plan.

Then teacher lack of ability in the use of technology has led to unprofessionalism in creating lesson plans and obtaining subject matter. Based on the data found, it stated that there are still some teachers who have not fully mastered their subject matter even though they have received certification. This is because the teachers only rely on their existing knowledge without trying to obtain new information or knowledge from other media and there is no motivation for the teachers to seek more, even other data shows that when teaching hours are empty many teachers prefer to open their gadgets rather than learning further or gaining knowledge.

Certification also has not played a significant role in the teacher's professionalism in the field of personality competence. One of the inhibiting factors in teacher professionalism for personality competence is a lack of discipline, where without supervision from their supervisor there are still teachers who are found to be late and have lack of responsibility in conducting their job. Until now there a quite number of teachers who have done the certification process. But not all of them have the quality of education personnel in accordance with the predetermined competencies, for field namely Pedagogic, Professional and personality competencies. Additionally, no matter what policy being implemented by the government, if the educator hired is unqualified then the purpose of the policy itself will not be 
achieved, and no matter how excellent the proposed curriculum is if the educators are not able to implement it well then it will be a useless measure. Besides having a great skill of teaching, teachers are also required to have extensive knowledge, wise attitude and socialize well, therefore, there is no guarantee that an educator who has received certification will become a professional educator.

\section{Conclussion}

The implementation of the elementary school teacher certification policy in Kuala Simpang District of Aceh Tamiang Regency has not been run effectively, this is due to poor facilities and infrastructure for its socialization and from 2012 until now there has not been any socialization of teacher certification. The related party from the Aceh Tamiang District Education Office has not been able to provide the best solutions towards the problems faced by the teachers, especially in responding to the inconsistent regulation in almost every year in the implementation of the candidates for teacher certification. Some of the obstacles found such as the inability of teachers to access information through the internet. Now, along with the development of the internet media (through the website) which has become more dominant for delivering and obtaining information rather than for face-to-face socialization. In the socialization of teacher certification, it is found that the guidebook for the teacher certification has not been distributed/ or not distributed equally to each teacher. The distribution of this guidebook is one of the jobs of the Aceh Tamiang District Education Office in terms of sharing information. Additionally, inconsistent regulations that are always changing has become an obstacle for teachers in participating in teacher certification. Based on these constraints, it can be stated that certification has not played a significant role in the professionalism of the certified teachers.

\section{References}

1. Bakar, R. (2018). The Influence of Professional Teachers on Padang Vocational School Students Achievement. Kasetsart Journal of Social Science, 39, 67-72. doi:https://doi.org/10.1016/j.kjss.2017.12.017

2. Edward, G. C. (1980). Implementing Public Policy. Washington DC: Texas A\&M Congressional University: Congressional Quaartterlt Press.

3. Fahmi, M., Maulana, A., \& Yusuf, r. A. (2011). Teacher Certification in Indonesia: A Confusion of Means and Ends. Center for Economic and Development Studies, 1-20.
4. Khan, Z. N. (2013). Need for Improvement of Teacher Education In the New Millennium. International Journal of Secondary Education, 1(2), 4-7. doi:doi: 10.11648/j.ijsedu.20130102.11

5. Kurniawan, B. D. (2011). Implementasi Kebijakan Sertifikasi Guru dalam Rangka Meningkatkan Profesionalitas Guru di Kota Yogyakarta. Jurnal Studi Pemerintahan, doi:http://dx.doi.org/10.18196/jgp.2011.0015

6. Kusnandar, I. (2018). Analysis of Certificatiion Policy Implementation. Journal of Education, Teaching and Learning, $129-134$. doi:http://dx.doi.org/10.26737/jetl.v3i1.602

7. Prasertcharoensuk, T., Somprach, K.-1., \& Ngang, T. K. (2015). Influence of Teacher Competency Factors and Students Life Skills on Learning Achievement. Procedia- Social and Behavioral Science, 566-572. doi:https://doi.org/10.1016/j.sbspro.2015.04.021

8. Supriatna, E. (2006). Administrasi Birokrasi dan Pelayanan Publik. Jakarta: Nimas Multima. 